\title{
The Relevance of Typology for Pattern Replication
}

\author{
Robin Meyer \\ Faculty of Linguistics, Philology, and Phonetics, University of Oxford \\ robin.meyer@ling-phil.ox.ac.uk
}

\begin{abstract}
Structuralists and generativists have insisted for a long time that the elements and structures one language could borrow from another are constrained by typological compatibility, naturalness, and other factors (cf. Thomason and Kaufman 1988: 13-34). Such constraints are still thought to apply to structural interference, or pattern replication in the terms of Matras and Sakel (2007), and the often concomitant contactinduced grammaticalisation of non-native structures.

This paper suggests that a priori there are no typological constraints against pattern replication in general. It is proposed that typological differences between model and replica pattern are only of relevance during the grammaticalisation and maintenance of such patterns in the replica language; in other words, typological constraints do not apply at the stage of pattern replication. It will be argued that typology, in the form of system pressure, interacts with pattern frequency and socio-historical factors, which together determine retention, adaptation, or loss of a replicated pattern.

This argument is illustrated on the basis of three short studies of partial alignment change in Old Aramaic, Classical Armenian, and North-Eastern Neo-Aramaic, all of which have been in contact with Iranian languages for extended periods. In each case, Iranian ergative alignment patterns have been replicated, adapted, grammaticalised to varying degrees, and finally ousted in favour of nominative-accusative alignment. The loss of the replica pattern in each case is shown to be dependent on both typology, extent of bilingualism, and pattern frequency.
\end{abstract}

\section{Keywords}

pattern replication - metatypy - ergativity - alignment change - Iranian

\footnotetext{
(C) ROBIN MEYER, 2020 | DOI:10.1163/19552629-01203002
}

This is an open access article distributed under the terms of the prevailing CC-BY-NC License at the time of publication. 
For most of the $20^{\text {th }}$ century, theoretical approaches to language and linguistics suggested that structural interference, that is the adoption of non-native (morpho-)syntactic structures or categories as the result of contact with another language, is very unlikely to occur (Givón, 1979: 26) or can occur only in very specific circumstances, e.g. between languages with very similar grammatical systems (Meillet, 1921: 87). More recent work, however, has highlighted that under the right socio-historical circumstances, usually involving intense and prolonged contact, structural interference does occur with apparent disregard for any purely linguistic constraint. In other words, "any linguistic feature can be transferred from any language to any other language" (Thomason and Kaufman, 1988: 14) as long as this transfer does not violate overarching constraints, e.g. as regards grammaticalisation (cf. Heine and Kuteva, 2008); the latter constraint is not restricted to structural transfer, of course, but applies to non-contact scenarios as well. ${ }^{1}$

Particularly in the case of structural transfers (or grammatical calquing), ${ }^{2}$ it remains disputed whether its occurrence is indeed linguistically unconstrained and bound mainly by socio-historical context (cf. Thomason, 2003; 2008), or whether some kind of linguistic constraint remains in play. ${ }^{3}$

1 The process of structural transfer, and specifically the replication of use patterns, does, however, require the existence of certain parallels in the usage of linguistic structures that can serve as the basis for replication of non-native structures, e.g. polysemy copying and pivot matching (cf. Heine and Kuteva 2005: 40-44; Matras, 2009: 234-264).

2 In the rest of the discussion, a more specific model of structural transfer, namely pattern replication, is used. It is here understood to be "a procedure by which pivotal features of the model construction are identified and replicated in the replica language" (Matras, 2009: 241; cf. Matras \& Sakel, 2007). This term is preferred over grammatical calquing etc. for not implying a direct copy of the model construction in the replica language; rather, replicated patterns are adapted to fit the grammatical categories and material available in the replica language so that "each is created within the rules of its own self-contained system, but they share a general design" (Matras, 2009: 247).

3 Myers-Scotton (2002) focusses on the explicative strength of theoretical linguistic models such as the 4-M model, which are, however, largely restricted to the realm of morphology (Myers-Scotton \& Jake, 2000). Thomason's observations suggest that 'anything goes' in language contact given the right socio-historical setting and intensity of contact; yet, while likely types of change can be predicted under the right circumstances, "the availability of at least two distinct and independent linguistic systems greatly expands the immediate possibilities for change" (Thomason, 2008: 54), making specific predictions impossible. 
The concept of markedness ${ }^{4}$ has frequently been noted as one of the possible constraints at the heart of language contact (Thomason and Kaufman, 1988: 194, 213; Myers-Scotton, 2002: 190-1; Heine and Kuteva, 2005: 256). In this context, the definition of markedness derives "primarily from typology (more widespread $=$ less marked), and secondarily from first-language acquisition (first learned = less marked)" (Thomason and Kaufman, 1988: 26-7). ${ }^{5}$ Unsurprisingly, the lack of a clearer definition and the opaque and relative nature of markedness have called into doubt its validity, leading to suggestions that the concept best be abandoned (e.g. Myers-Scotton, 2002: 231; Haspelmath, 2006).

The notion of markedness, or an intimately related concept, is still applied in a more clearly defined form in the guise of typological distance, ${ }^{6}$ which suggests that elements and patterns in the model language diverging typologically from parallel ones in the potential replica language are less likely to be adopted, at least in casual and moderate contact situations; this constraint applies mostly to phonological and syntactic interactions (Thomason and Kaufman, 1988: 72). In the realm of syntactic borrowings (or pattern replication), however, this constraint is not infrequently violated, ${ }^{7}$ wherefore the question arises whether (like markedness as a concept, or at least as a technical term) typological distance had best be set aside as a criterion in considering language contact processes, or whether it can be retained in a different role.

In what follows, the relevance of typological distance for transfer in language contact will be considered on the basis of three case studies of syntactic pattern replication which resulted in partial, temporary alignment change.

4 Authors differ with regard to their definition of markedness; some use it as a shorthand for 'unexpected' phenomena in a contact language, others as a way of referring to learnability or 'transferability' of a particular structure. This issue is discussed further in section 2 below.

5 That is to say that, on the one hand, cross-linguistically more common patterns, e.g. nominativeaccusative alignment or sov word order, are less marked than less frequent patterns, e.g. tripartite alignment or osv word order (cf. Tomlin, 1986: 22). At the same time, for a native speaker of a language with a cross-linguistically less common pattern (e.g. Warao in NE South America), the universally less marked patterns would be more marked. Therein lies one of the problems of the concept of markedness.

6 One approach to defining typological distance is the comparison of structural data from both languages concerned, e.g. as recorded in the World Atlas of Language Structures (wALS). For a recent application and description of such a comparison in the field of language contact, see Seifart (2015: 94-6).

7 They suggest that "in slight to moderate borrowing, source-language features that fit well typologically with functionally analogous features in the borrowing language tend to be borrowed first" (1988: 72); rather than a constraint, this appears to be an order of precedence, dictated as much by socio-historical factors as by typological distance. 
The three replica languages - Syriac, Classical Armenian, and North-Eastern Neo-Aramaic (NENA) - have each been in contact with an Iranian language and have adopted their split-ergative system, but to different degrees, at different times in history, and under varying socio-historical circumstances.

Since the replication of ergative-absolutive patterns in the model languages occurred in spite of significant typological distance to the otherwise nominativeaccusative replica languages, and under a number of different circumstances, it is worth considering whether typological distance can indeed be said to constrain pattern replication. The concept of an aprioristic restriction against borrowings from typologically divergent languages is best replaced by an 'anything goes in language contact - under the right circumstances' approach. ${ }^{8}$ Divergent patterns may be borrowed and even grammaticalised in the replica language (given the right socio-historical circumstances), but can also be ousted by native patterns. This outcome is most likely if the borrowed element is used infrequently, contact with the model language has declined significantly, or systemic pressure from more dominant patterns make it necessary. ${ }^{9}$

These three factors ('centrality' of the pattern; 'constancy' of contact; 'consistency' with native, replica language patterns), varying in each contact situation, are of primary concern in determining whether a pattern is replicated, grammaticalised, and maintained in the replica language. For reasons of space and clarity, the discussion of typological constraints and their relevance to language contact situations in this paper is intentionally restricted to instances of syntactic change only; phonological, morphological, and other changes may be subject to different tendencies.

8 Cf. Thomason (2008). This refers to traditional language contact situations arising in communities of bilingual speakers of varying degrees of proficiency, in which an individual speaker's innovation may or may not spread. Different mechanisms apply in instances where bilingualism is absent or severely limited, e.g. in the genesis of pidgins.

9 Infrequently used expressions or patterns are less likely to be retained, while less contact or lower-level bilingualism decrease the amount of patterns available for replication and the number of speakers as agents of change. In turn, frequency and intense contact are able to counteract systemic pressure on both a morphological and syntactic level; non-contactinduced comparanda include the retention of morphologically irregular paradigms for high-frequency verbs in numerous languages (NE go : went; Fr. je vais : nous allons, etc.) as well as the maintenance of genitive objects after certain common verbs (bedürfen, sich vergewissern) in Standard High German as opposed to the imposition of standard accusative objects. 
In order to substantiate this point, the arguments in favour and against a typological markedness constraint are revisited in section 2 by means of a brief recapitulation of relevant cases cited in the literature. Section 3 discusses the concept of metatypy (as per Ross, 2007) and illustrates the reasons why instances thereof are ideal cases to investigate the constraint in question. In turn, section 4 outlines three instances of syntactical pattern replication, proposing that the metatypical changes found speak against a typological constraint, since markedly similar replication processes occurred in very different settings and with comparable outcomes. Finally, section 5 draws together the evidence gathered and outlines a different approach to dealing with typological divergence in language contact situations.

Markedness, Typological Distance, and Pattern Replication

In an influential paper, Haspelmath (2006) points out the polysemy of the linguistic term markedness, subdividing it into twelve senses and dispelling its assumed usefulness as a concept in linguistics. To give but two examples: a specific semantic distinction may be marked, regarding for example its inclusivity; the unmarked German Hund 'dog' can refer to a canine of any gender, whilst its feminine counterpart Hündin 'bitch' exclusively refers to female members of the species (cf. Jakobson, 1971: 3-4; Haspelmath, 2006: 28-9). The feminine form is, therefore, more marked since it is less inclusive, referring only to a subset of instances of the concept 'dog', whereas the masculine form refers to all subsets.

A correlated notion is that of markedness as morphological difficulty..$^{10}$ The English plural formation in glove:gloves, for instance, is considered unmarked owing to the correspondence of semantic (plural) with morphological marking (-s); the pair ox:oxen or moose:moose, on the other hand, are marked since the former uses a non-standard plural form, and the latter bears no morphological marking correlating to its plural semantics. Accordingly, both of the latter instances 'strain the human language capacity' and are thus marked (Wurzel, 1998: 63).

Countering Rice's suggestion (2003: 390) that 'capturing exactly what markedness means is by no means a straightforward task' but that linguists have come to have a strong intuition about it, Haspelmath suggests that

10 This is not to be confused with the original notion of morphological markedness, i.e. the marking of a feature by means of a morpheme. 
'linguists can dispense with the term 'markedness' and many of the concepts that it has been used to express. It can be readily replaced by other concepts and terms that are less ambiguous, more transparent and provide better explanations for the observed phenomena" (Haspelmath, 2006: 63).

In the specific context of typology, the notion of markedness has been used to refer to the co-occurrence of certain structures or patterns; a pattern $\mathrm{A}$ is considered marked in relation to pattern $\mathrm{B}$, iff languages with $\mathrm{A}$ also always contain B, but not necessarily vice versa (Eckman, 1977: 320). An instance of this typological markedness can be found in, e.g., Greenberg's Universal 34: 'No language has a dual unless it has a plural' (1966: 94); since it follows that all languages with a dual category also have a plural category, but not all languages with a plural also have a dual, the dual is a universally marked feature.

When considering language contact, however, next to such universally marked features, it is necessary to consider those features, categories, or structures which are 'relatively' marked. In particular, these are features, etc. which fit typologically into the model language, but do not occur natively in the replica language. To give an example pertinent to the discussion below: from the perspective of an otherwise nominative-accusative replica language, ergativeabsolutive alignment is 'relatively' marked; in this context, it is irrelevant whether ergative-absolutive alignment is universally marked. This relative markedness is an expression of the typological distance between model and replica language. Following Haspelmath's suggestion and for the sake of clarity, the discussion below eschews the term markedness, and will instead refer to typological distance. This typological distance is one of the key factors to which the likelihood of a model language structure being borrowed in the replica language has been correlated. It might act as a borrowing constraint: the greater the distance, the less likely is borrowing (Givón, 1979: 26; also cf. already Meillet, 1921: 86-7).

Further, in the case of pattern replication, it is difficult to judge the effectiveness of such a proposed constraint, since its application does not effect change; ${ }^{11}$ the result is essentially an argumentum ex silentio. This is further

11 In instances of phonological borrowings, this is true in principle, too, since the lack of replication of phonotactic or morphophonemic rules cannot be observed. With regard to material replication, however, the inverse is true: if lexical items are borrowed, they either need to be adapted to the phoneme inventory of the replica language, or that inventory needs to be appended. That of Standard High German, for instance, contains a voiced palatal affricate [ $\left.\hat{d}_{3}\right]$ and a voiced palatal fricative [3], which are exclusively found in loanwords such as Dschungel 'jungle' or Journal 'journal'; in some dialects, however, the repli-

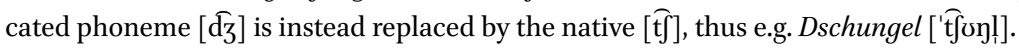


exacerbated by the fact that pattern replication, where it can be shown to occur beyond reasonable doubt, is almost exclusive to intense contact situations with wide-spread bilingualism (Thomason, 1997; Aikhenvald, 2007), thus limiting the set of potential cases to be studied.

Weakening the base of this supposed typological markedness constraint even further, it is precisely in these intense contact environments where contraindicated, typologically distant constructions are replicated (see section 4 for examples in greater detail). A few examples from the literature will serve to illustrate this: Indo-European languages typically have person categories roughly equivalent to those in modern Western European languages like French, English, or German, with three persons in singular and plural..$^{12} \mathrm{~A}$ small set of Indic languages, such as Sindhi and Gujarati, however, has added a category by differentiating between an inclusive and exclusive 'we', a distinction found in a neighbouring Dravidian language (Emeneau, 1962: 56). ${ }^{13}$ Another Indic language, Šinā, has gone so far as to adopt the ergative alignment pattern of the neighbouring Tibetan language Balti (Verbeke, 2013: 256-7; Anderson, 1977: 344). In the Americas, Silverstein $(1977 ; 1974)$ reports on the creation of a gender system in proto-Chinookan "under heavy categorial influence from the languages surrounding on the coast" (1977: 154), specifically Tillamook, Chehalis, and other Coast Salish languages.

Already Thomason and Kaufman state that a typological distance constraint is more honoured in the breach than the observance:

"The evidence we have collected that bears on this point does not permit a firm conclusion about the validity of the general hypothesis [concerning the role of typological distance]. [...] We have solid evidence from cases of heavy structural borrowing (e.g., Ma'a, Asia Minor Greek) and even moderate structural borrowing (e.g., various contact situations in India) that features can and do get borrowed regardless of their typological fit with borrowing-language features." (Thomason and Kaufman, 1988: 53$)^{14}$

12 The dual category, which occurs more widely in classical languages such as Sanskrit and Greek, has survived only in some modern Slavic languages like Slovene, and in some registers of Lithuanian (cf. Mayer, 1973; Jakop, 2012; Strazny, 2013: 120).

13 Many languages are, of course, able to express clusivity by means beyond inflectional morphology, e.g. Ital. noialtri (exclusive); yet, the standard pronouns or verbal forms in these languages are ambiguous as to clusivity.

14 Thomason maintains this view in her more recent work, e.g. Thomason (2000; 2001; 2008), and is backed by others (cf. Aikhenvald, 2007; Heine and Kuteva, 2003; Curnow, 2001; Harris and Campbell, 1995). Yet, as Heine and Kuteva (2008) point out, the development of 
They do suggest, however, that this constraint should apply "in cases of light to moderate interference" (1988: 54$)$.

In view of even these few examples, the plausibility of a constraint or even tendency so readily overridden must be called into question; either it is to be discarded entirely, or its parameters and effects are to be defined more closely. As it stands, the constraint does not apply in casual or less intense contact situations, where pattern replication generally is not observed and only non-basic lexicon is likely to be borrowed. In more intense contact situations, where pattern replication has been noticed most frequently, there are numerous cases of constraint violation as just mentioned, ${ }^{15}$ yet, such morphosyntactic borrowings are still more common in instances where there is no typological distance between model and recipient language in the pattern concerned (Thomason and Kaufman, 1988: $5^{2-3}$ ).

The key to resolving this apparent discrepancy lies not in abandoning the typological distance constraint entirely, but in repositioning it. Contrary to Silva-Corlvalán's assertion that 'every change allowed appears to be constrained by the structure of the affected language' (2008: 221), it appears that in principle anything is possible in language contact under the right sociohistorical circumstances (Thomason and Kaufman, 1988; Campbell and Muntzel, 1989; pace Myers-Scotton, 2002), and that pattern replication relies on the accessibility of the pattern in question during language processing, irrespective of the language produced. This common accessibility is to be expected for patterns occurring in both languages, but also applies to bilingual contexts or in L2 acquisition, where code-switching bilinguals may need (or want) to 'replicate a function that exists in the model language' (Matras, 2009: 239) by using non-native patterns available in their mental grammar (cf. Heine and Kuteva, 2005: 92; 2003: 539). Such erroneous or consciously deviant usage of non-native patterns is transient during language acquisition and learning, and does not in itself predict whether a foreign pattern will be grammaticalised or not. Yet once a model language pattern has been used in the replica language (no matter under which circumstances), pattern replication is a distinct possibility.

replicated patterns is constrained by factors similar to those underlying other language change processes, e.g. as regards the direction of grammaticalisation: volitional verbs may be grammaticalised as a future tense, but a future marker does not yield a volitional expression.

15 More specific social factors appear to play a very limited role here as long as bilingualism is widespread: in the case of Šīnā, influence arises from a minority language, Balti; Asia Minor Greek, however, as mentioned by Thomason \& Kaufman $(1988: 45,53,94)$ is influenced by the more dominant Turkish. More examples of different socio-historic environments are given in section 4 . 
Accordingly, it is argued in what follows that grammaticalisation and longterm retention of such patterns in the replica language depend on a number of factors: 'centrality', that is the usage frequency in communication of the structure in question; 'constancy', viz. constant contact with the model language, concomitant bilingualism, and thus active usage of the model pattern; and 'consistency' with replica language typology, or in other words, maximal crosssystem harmony between the languages involved. ${ }^{16}$ That is to say that any kind of pattern may, in principle, be replicated in spontaneous speech acts of proficient or imperfect bilinguals, with varying degrees of modification to the pattern in order to adapt to morphosyntactic categories of the replica language; the grammaticalisation of such a pattern and its maintenance in the replica language is contingent on its frequent recurrent usage and the continuation of the language contact environment in which the pattern was established. These two factors are, in turn, counterbalanced by the typological distance, or perceived 'difficulty', of the pattern: a more intense contact situation and/or very frequent use of the replicated pattern can accommodate the grammaticalisation of more typologically divergent patterns. Since the typological factor is often diachronically more constant, ${ }^{17}$ changes in the contact situation or frequency of use affect this balance, and may result in further adaptation of the replicated pattern to the typology of the recipient language, its marginalisation, or ousting.

A typological constraint, such as a constraint against borrowing syntagmata requiring a different morphosyntactic alignment pattern, or typological distance more broadly speaking, is therefore not an a priori blocking mechanism of pattern replication in language contact, but rather one of multiple factors determining the eventual grammaticalisation, stability, and longevity of an extraneous pattern. It is not typological considerations that are at the heart of

16 Haig (2008: 192-3) suggests that cross-system harmony is the key to alignment change and diverse case marking systems of West Iranian languages; the underlying idea is that languages intrinsically strive for a system in which "clauses expressing the same basic propositional content will exhibit the same constellation of formal morphosyntactic features: word-order, case-marking, and agreement."

17 Typology is, of course, not immune to linguistic change, but is unlikely to transmute significantly in one generation of speakers; in contrast, political and social changes can occur far more rapidly. Compare, e.g., the rapid socio-economic and cultural changes on the territory of the former GDR in the 1990s resulting from the end of the Cold War (including the loss of importance of Russian as a second language), with the tenacity of verb-final position in subordinate clauses in German despite internal pressure from verb-second main clauses, culturally important contact languages such as English and French, and lectal divergence in e.g. Bavarian or Kiezdeutsch (cf. Weiss, 1975: 31, 57; Schröder, 1984: 136). 
pattern replication, but rather the community of bilingual speakers and their circumstances. Following Haspelmath's attempt at eliminating the unnecessary term markedness, the phenomenon owing to which pattern replication is more common in typologically similar languages is probably best described as a combination of frequency effects and, in Haig's (2008: 193) terms, a tendency for language-internal systemic harmony.

Typological Changes through Contact: Metatypy and Metatypical Changes

A substantiation of this proposal requires that the interplay of these three determining factors (centrality; constancy; consistency) can be shown to apply in instances of pattern replication; in what follows, the focus will lie on instances violating the typological distance constraint (consistency).

Briefly returning to the cases of pattern replication mentioned above, it is evident that the replicated morphosyntactic patterns or categories mentioned are not affected by this constraint: the addition of morphosemantic categories, such as gender or number distinction, is not liable to reduction through systemic pressure within the replica language, since the syntax of these systems is expanded rather than altered; as long as such new categories are actively used, they present no challenge to native patterns. Whilst the persistence of contact is difficult to evaluate in the case of Proto-Chinookan, both Šinā, Sindhi, and Gujarati are still in contact with the model language from which they borrowed patterns. In the case of Šinā, the contact-induced occurrence of ergative marking in the imperfective system is also unproblematic in view of the preexisting ergative alignment of the perfective system; that ergativity is realised in different ways in each system is of little consequence (Verbeke, 2013: 257).

This type of alignment change can, however, pose more significant problems for the notion of typological constraints or consistency since, by their nature, (partial) alignment changes work against the typological grain of a language. Before delving into the details of three examples of such changes in section 4, it is worthwhile considering the process from a more theoretical perspective as suggested in the form of metatypy by Ross (2007).

According to Ross, metatypy should be defined as a

"diachronic process whereby the morphosyntactic constructions of one of the languages of a bilingual speech community are restructured on the model of the constructions of the speakers' other language, such that the constructions of the replica language come to more closely match 
those of the model language in both meaning and morphosyntax." (Ross, 2007: 124).

As opposed to previous suggestions (Ross, 1996; 1997; 2001; 2003), however, he distinguishes lexical and grammatical calques, which function as necessary precursors, from the process of morphosyntactic restructuring itself. The difference is illustrated by means of contact-induced changes in Mixe Basque, where on the basis of Gascon models complex adpositions and a passive voice have arisen, and Yiddish, which has partly remodelled a Germanic focus construction on Slavic patterns. Both instances, according to Ross, do not constitute metatypy, however, since the changes in Mixe Basque represent changes in categories and their membership, not syntax (2007: 127). Similarly, the Yiddish example is taken to be "direct copying" of the Slavic model, rather than change in recipient language structures through imitation (2007: 129).

The border between grammatical calquing and metatypy is thus, understandably, fuzzy at times: calquing is a prerequisite for metatypy, but not a sufficient condition; equally, the syntactic restructuring required in order to qualify as metatypy becomes more complicated, and thus more unlikely, the more typologically distant the languages are; yet a decrease in likelihood does not equal a constraint.

It is for this very reason that instances of metatypical changes ${ }^{18}$ are of particular interest in considering the above hypothesis concerning typological distance: if metatypy, or changes bordering thereon, can be shown to have occurred in typologically sufficiently distinct languages, this would reinforce the operational invalidity of the typological distance constraint. In turn, if metatypy is prevented despite the occurrence of grammatical calques that might have led to it, the circumstances of such a lack of metatypy should be illuminating. Only such instances of typological change, however, as would be unlikely to occur without external influence will be admissible as evidence..$^{19}$ If, therefore, metatypical changes due to language contact in languages exhibiting

18 In what follows, a distinction between metatypy in the meaning suggested by Ross (2007) and metatypical changes will be maintained; the latter are to be understood as partial metatypy, that is changes such as might lead to metatypy eventually, or have influenced the syntax or semantics of only specific systems in the replica language.

19 The occurrence of a type of development unlikely to occur 'naturally' in a particular language is relevant in so far as to disprove the notion suggested by Vogt (1954: 372) that even language contact can only effect "innovation possibilities offered by the receiving system" (also cf. Harris and Campbell, 1995: 123-7). 
typological differences can be shown to be transient, restricted to a certain system, or influenced by non-typological factors, this would further speak against a typological constraint in language contact, and indeed in favour of the notions of centrality, constancy, and consistency proposed above.

In this section, three instances of contact-induced syntactic change are discussed in greater detail; in each instance, the verbal system of the recipient language has, to a greater or lesser extent, adapted to that of the respective Iranian model language.

The first case concerns changes in Old Aramaic, which on the basis of contact with Old Persian has developed a participle-based past tense with a prepositional agent. Both languages were spoken in antiquity: Old Persian is first attested in the late sixth century BCE as one of the influential languages of the Achaemenid Empire, and ceased to be used in inscriptions in the late fourth century ВСЕ (Skjærvø, 2009: 46-7); Old Aramaic was used as the lingua franca of the region before, during and after the Achaemenid Empire. ${ }^{20}$

A second case is presented by substantial influence on Classical Armenian from the Western Middle Iranian languages, foremost among which Parthian. Armenia was first recognised as a distinct entity in the late sixth century вСЕ; its inhabitants clearly had a distinct language throughout antiquity, ${ }^{21}$ which however is only attested from the fifth century CE onwards, after the invention of the Armenian alphabet. Beginning and end of Parthian influence are difficult to determine: a conservative date-range begins with the installation of a Parthian king over Armenia in $66 \mathrm{CE}$, and ends with the abolishment of Parthian rule under the Sasanians in $428 \mathrm{CE} .{ }^{22}$

The final case concerns dialects of North-Eastern Neo-Aramaic (NENA), which have been in contact with Kurdish dialects for extended periods of time.

20 Cf. Frye (1955); for more information on Old Persian and Old Aramaic in general, see Rosenthal et al. (1986) and Schmitt (1989; 2008), respectively.

21 Strabo (Georgraphy XI.14.5) mentions that in the $2^{\text {nd }}$ century вСЕ the same tongue was spoken throughout the lands under Armenian control, including the Kingdoms of Sophene, Commagene, and Armenia proper.

22 Less intense contact with Parthian and other Iranian languages is likely to have started far earlier. As an Achaemenid and later Seleucid satrapy, Armenia was for centuries ruled at least indirectly by Iranians; Russell (1997: 37) summarises the situation in stating that from the Achaemenid conquest "[u]ntil the conversion of the Armenians to Christianity, with its Byzantine and Syrian cultural and political links, Armenia was to remain in the Iranian cultural orbit almost exclusively". 
Both Kurdish and NENA dialects vary greatly as regards their grammar, owed to no small extent to the geographic dispersion of the speaker communities and varying contact languages. The particular case considered here is that of the Jewish dialect of Sulaymaniyah, which has been in contact with the local Sorani Kurdish dialect for at least two centuries. For each case, a brief socio-historic introduction is followed by an explanation of the original patterns of the verbal system that later underwent syntactic changes through contact with the relevant Iranian language (where possible).$^{23}$ Thereafter, both Iranian model and the replicated pattern based thereon will be discussed. Where possible, the history of the pattern shall be traced and socio-historic elements examined as necessary.

\subsection{The Old Aramaic qtyl l-construction and Old Persian}

Old Aramaic ${ }^{24}(\mathrm{OA})$ was the lingua franca of the Achaemenid Empire and as such was in prolonged contact with Old Persian. ${ }^{25}$ Having been the language of Aramean city states prior to their annexation by the Neo-Assyrian Empire, Old Aramaic had gained its status independently from the invading Achaemenids; its function as a means of communication between the various parts of the Empire, each with their own dominant language, is in part owed to its script. ${ }^{26}$ The contact between the two languages is reflected not only in translations of Old Persian material, such as the Behistun inscription, into Old Aramaic, but also in numerous lexical borrowings from Old Persian into Old Aramaic. ${ }^{27}$ They consist largely of legal and administrative terms such as OA 'ȟšdrpn' 'satrap' < OIr. *x̌̌šrapāna- or OA ptyprs 'retribution' < OP *patifrāsa-, but also

23 While considerable amounts of Old Aramaic and Classical Armenian texts are translations from other languages, the examples given below are all from non-translated texts.

24 The specific phase of the language in question is also referred to as Imperial Aramaic. Old Aramaic in itself was not entirely internally homogeneous (cf. Ciancaglini, 2008: 11-12; Kutscher, 1970: 316ff.).

25 All stages of Old Aramaic are well documented in letters, other papyrus and leather documents, and inscriptions (cf. Ciancaglini, 2008: 12; Kaufman, 1997: 115-6); Old Persian is known almost exclusively from lapidary inscriptions. The extent of contact between the languages is difficult to determine, since sources provide no information in this regard. Widespread multilingualism beyond the upper classes and scribes seems unlikely.

26 The Phoenician-based abjad used for Aramaic proved easier for recording purposes than the complex cuneiform scripts of Old Persian, Elamite or Akkadian (Rosenthal et al., 1986).

27 These loanwords are attested both in administrative documents from Egypt, lapidary inscriptions from Persepolis, and in literary sources such as the Aramaic books of the Old Testament, Ezra and Daniel (cf. Hinz, 1975; Henning in Rosenthal, 1963: 58-9). 
include lexical items referring to less abstract, more quotidian objects, e.g. OA prds 'garden' < OP paridaiza- (cp. Engl. paradise) or OA nbršt 'lamp' < OP *nibrāšti-. ${ }^{28}$

To a lesser extent, morphosyntactic calques also occur: these involve the use of connectives like OA ' hhr 'afterwards', based on OP pasāva 'id.', but also more complex structures like the replication of OP haya/taya-phrases-an early form of the ezāfe-construction found also in Avestan and numerous later Iranian languages-, which express a genitive/possessive relationship between NPs, in the form of OA $z y$ instead of a construct chain typical for Semitic languages (cf. Whitehead, 1978: 128-35).

While the latter innovation is noteworthy, it is an addition to the verbal system that is of greater significance. The origin of this replicated pattern is thought to be the Old Persian taya manā krtam construction, which has been variously analysed over the past century; while some have taken its origins to lie in a possessive construction akin to 'have'-perfects in other Indo-European languages (Benveniste, 1952), others have suggested it to be the first sign of a split-ergative system as occurs later in the Middle Iranian languages (Haig, 2008; Jügel, 2015; 2010). ${ }^{29} \mathrm{~A}$ passive reading cannot be excluded entirely, but is unlikely on numerous grounds. ${ }^{30}$ Example (1) illustrates this pattern:

\begin{tabular}{|c|c|c|c|c|}
\hline ima & taya & manā & krtam & pasāva \\
\hline DEM.NOM.SG.N & REL.NOM.SG.N & 1.SG.GEN & do.PTCP.NOM.SG.N & after \\
\hline$y a \vartheta \bar{a}$ & 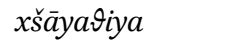 & abavam & & \\
\hline when & king.NOM.SG.M & become.1.SG.PST & & \\
\hline
\end{tabular}

In all instances of the construction, the participle occurs together with an agent in the genitive case and patient in the neuter nominative/accusative, while a

28 The forms preceded by an asterisk have been reconstructed on the basis of later Iranian forms, or are paralleled by similar formations, so e.g. OP xšaçapāvan- 'satrap'.

29 With the exception of this construction, Old Persian follows a nominative-accusative alignment pattern in all tenses; the agent in a passive construction is usually marked by haca 'by' + ablative. There are four tenses, present, imperfect, aorist, and perfect, of which the latter two are poorly attested; four moods are attested for the present (indicative, subjunctive, optative, imperative), and there are three voices (active, middle, passive).

30 Old Persian has a synthetic passive, which for the relevant verb 'kar- 'do' is attested in the 3.SG.PST.PASS as OP akariya. Another indicator is that in the majority of the few attested passives in which expressions of agency occur, the postposition OP hacā is used. Other considerations, such as animacy of the agent, further disfavour this analysis . 
finite form of the copula does not frequently accompany the construction. ${ }^{31}$ This taya mana krtam construction is of interest for two reasons: first, a genitive agent is not widely attested in Old Persian in either active or passive construction, finite or non-finite, ${ }^{32}$ while the genitive is not a prototypical agentive case (cf. Hettrich, 1990: 94, 97; Jamison, 1979: 133-7), similar constructions exist in Avestan and Sanskrit (cf. Cardona, 1970). Secondly, the construction is attested only with the verb 'kar- 'to do, make', which raises questions concerning its status in Old Persian. ${ }^{33}$

Despite the scholarly attention that has been paid to the taya mana krtam construction and related syntagmata in later Iranian languages, the pattern is synchronically rather limited in scope. Limited to ${ }^{\circ} \mathrm{kar}$ - in the Old Persian inscriptions, it must have gained greater currency by Middle Iranian times, since its successor became the standard past tense of the Western Middle Iranian languages (see section 4.2 below).

According to Coghill (2016: 165-170), Ciancaglini (2008: 32), Pennacchietti (1988: 104), the Old Aramaic qtyl $l$ - construction, which consists of a passive participle and a prepositional phrase ( $l$ - and enclitic pronoun), is based on this Old Persian model; ${ }^{34}$ in both instances, the agent of the action expressed by the passive participle occurs in a form normally associated with possession and indirect object marking. Like the genitive case in Old Persian, the preposition $l$ - 'to, belonging to' in Aramaic is used to indicate the indirect object, but not the passive agent, for which the preposition $\min$ 'from; by' is employed instead. In Old Aramaic, the $q$ ty $l$ - construction serves as a resultative perfect, and like its Old Persian counterpart is restricted to certain verbs: initially, only

31 Old Persian has syncretised the inherited Indo-Iranian genitives and datives into a single case, here referred to as the Old Persian genitive, which has taken on the functions of both cases, thus expressing both possession or appurtenance as well as marking the indirect object, recipient, and related notions (cf. Brandenstein and Mayrhofer, 1964: 55).

32 There are, however, two instances where the Old Persian genitive enclitic $=\check{s} \bar{a} m$ is used to convey the passive agent even with finite verbs (DB V.15-16, DB V.31-2).

33 Benveniste (1952: 54) suggests that a further participle used in this construction may be found in DNb 53 (OP xšnütam < ${ }^{\circ}$ šnav- 'to hear'); this is a restored form, however, and thus cannot count as sufficient evidence.

34 Ciancaglini (2008: 34) gives a number of reasons corroborating this suggestion: the qtyl $l$ construction only occurs in East Aramaic, the variety in contact with Old Persian; the first attested instance of this construction occurs in the writing of a Persian satrap, Aršāma; the Aramaic translation of the Old Persian Behistun inscription does not use this construction to render the OP taya manā krtam, suggesting that its introduction must be dated later and did not yet exist in the earliest forms of Aramaic. For a more critical perspective, see Coghill (2016: 168-170). 
verbs of perception are found in the Old Aramaic construction. (2) presents a minimal example, and the first attestation of the construction.

(2) Old Aramaic (tad A6.10; Driver 7; Pell. Aram. I)

\begin{tabular}{lllll}
$w-k{ }^{\prime} n$ & $t n h$ & $k n$ & \multicolumn{3}{c}{$m y^{\prime}$} & $l-y$ \\
and-now & here & thus & hear.PTCP & to-1.sG
\end{tabular}

'And now, thus have I heard here [that ...]'

This pattern contrasts with the standard expression of subject and object in Old Aramaic, where neither bears explicit morphological markings; word order and verbal morphology indicate syntactic roles, as demonstrated by (3).

(3) Old Aramaic (tad A6.10; Driver 7 ; Pell. Aram. I) 'r]thy $y d^{\prime} \quad t^{\prime} m{ }^{\prime}$ znh PN know.3.sG.M command-EMPH this 'Arthaya knows this command.'

Here, the svo word order typical of later stages of Old Aramaic and semantics alone serve to indicate the syntactic roles of the constituents. ${ }^{35}$

Next to Old Aramaic, this construction also persists in some of its daughter languages, including Syriac, Mandaic, and Talmudic Aramaic. ${ }^{36}$ According to Kutscher (1969: 140), the construction was still fairly uncommon in the Pešițā; yet, it came to be used for verbs not only of perception, and included transitive and intransitive verbs (cf. Nöldeke, 1904: 219-20), as in (4) and (5).

(4) Syriac (Spic. 13,8)

qrēn l-äk ktābā

read.PTCP to-2.SG book.PL

'Have you read the books?'

(5) Syriac (Spic. 43,7)

mhallak $\quad l-\bar{\imath}$

stand.PTCP to-1.SG

'I have stood.'

35 Note that the standard word order of the earliest form of Old Aramaic was vso, like in other Old Semitic languages; sov order is not uncommon in Imperial Aramaic owing to influence from Iranian languages, but is eventually ousted by the shift to svo (cf. Kaufman, 1997: 127).

36 Next to its usage in the verbal construction discussed, $l$ - continues to be used as a preposition meaning 'to' in these languages (cf. Nöldeke, 1904: 191-3). 
In applying to intransitive verbs as well as transitive ones, the $q$ tyl $l$ - construction already deviates from its Old Persian model, and indeed from the Middle Iranian successor construction. The occurrence of explicit object marking of what should be the grammatical subject constitutes a further step away from that model, as in (6).

(6) SyriaC (am 3, 595, 13)

$\begin{array}{lllll}\text { kad } \quad \text { asīr } \quad l \text {-eh } & \text { l-sāțānna } & b \text {-šěšaltāa } \\ \text { CONJ bind.PTCP } & \text { to-3.SG.M } & \text { to-Satan } & \text { with-chain.PL } \\ \text { 'for he had bound Satan with chains' } & \end{array}$

Historically, then, the sequence of events must have been approximately as follows: the Old Persian construction is replicated in Old Aramaic, whereby the genitive pronoun is rendered as a prepositional phrase owing to a lack of case marking in the recipient language. ${ }^{37}$ Originally restricted to verbs of perception, its input widens to encompass other types of verbs, including intransitive ones; by the time of Syriac, the prepositional agent marker has been reanalysed as a subject, and previous grammatical subjects of the passive-intransitive participle may receive overt object marking.

It is important to note, however, that this construction never became the standard, and certainly not the only way of expressing the past in Old Aramaic or Syriac (Ciancaglini, 2008: 36); nor did it cause a typological change in the syntax of either language, since the $l$ - prefixed agent was neither adopted in other tenses, nor the standard for passive constructions in this tense. Conversely, it is of note that the replicated pattern was reanalyzed as an active construction, fitting into the syntax of Syriac as shown in (6). The Old Aramaic grammatical calque, which could have been the precursor of metatypy proper, survived in Aramaic on the fringes of the verbal system in spite of its typological differences such as syntactic role marking and the occurrence of subjects in a prepositional phrase. Owing to these, however, and to its apparent lack of centrality in Old Aramaic, as well as the loss of prestige of Old Persian after the fall of the Achaemenid Empire, system pressure resulted in the reanalysis of the pattern, which only then became more common in Syriac.

These metatypical changes may not have led to a change of syntactic alignment in Old Aramaic or Syriac, but, given the typological differences between model and replica language, clearly show that no typological constraint was in

37 As mentioned above, replicated patterns are not copies, but adaptations of their models, made to fit the grammatical categories and material available in the replica language. In this specific case, the shared features are the usage of a participle together with a nonstandard agent in a form otherwise used to express appurtenance. 
place during the replication process. Conversely, once replicated, the pattern was over time reanalyzed to fit into the replica language system.

\subsection{The Classical Armenian periphrastic perfect and Parthian}

The second case of pattern replication and metatypical changes, namely the periphrastic perfect in Classical Armenian, bears certain resemblances to the qtyl l- construction of Aramaic in that here, too, a second, non-native morphosyntactic alignment pattern emerges in one particular tense system as a result of language contact. The Armenian case, however, is somewhat more complicated, as detailed below.

Armenian is an Indo-European language once thought to belong to the Iranian phylum; since the seminal work of Hübschmann (1875), however, it is generally accepted that the Iranian 'appearance' of Armenian is in fact owed to long-lasting language contact with both Old and Middle Iranian languages. ${ }^{38}$ Classical Armenian was spoken in the Armenian highlands, roughly delimited by the Caucasus in the North, Media Atropatene (modern Azerbaijan) to the East, the Taurus Mountains to the South and the Upper Euphrates in the West; owing to political expansion in the $1^{\text {st }}$ century вСE, and close cultural ties to the Greek-speaking world, the language spread into Asia Minor and the Levant as well. While Armenian is only attested in written form from the $5^{\text {th }}$ century CE onwards, the first certain attestation of the Armenian people goes back to the Behistun inscription of the Achaemenid King Darius I, finished $5^{20}-518$ BCE.

Evidence from a limited amount of Old Iranian loanwords suggests that Armenian and Iranian speakers had been in close contact since that time at least; ${ }^{39}$ this is confirmed further by the political dominance of Iranian peoples over the Armenians. ${ }^{40}$ With minor intermissions, Armenia was ruled by Iranians in one fashion or another until the establishment of the marzpanate in 428 $\mathrm{CE}$, from which time government affairs were conducted by non-hereditary

38 Armenian is first attested in stone graffiti in the $5^{\text {th }}$ century CE; historiographical literature dating to the same time period is found in later manuscripts. Parthian, the main contact language, is attested both in ostraca ( $1^{\text {st }}$ century BCE), lapidary inscriptions and letters $\left(1^{\text {st }}-3^{\text {rd }}\right.$ centuries $\left.\mathrm{CE}\right)$, as well as literary texts from the $8^{\text {th }}$ century CE onwards (cf. Durkin-Meisterernst, 2014: 4-9). Once more, there is very little extralinguistic data which might provide insights into the extent of multilingualism, but Armenian literary accounts make it very clear that both cultures were intertwined for an extended period of time (cf. Garsoïan 1997a,b; Meyer 2017: 295-323).

39 For a more complete picture of Old Iranian loans in Armenian and the associated issues, Schmitt (1983) and Hinz (1975) currently provide the best overview.

40 The Orontid (or Eruandid) dynasty that ruled over Armenia in the times of the Achaemenid Empire had a privileged position, and its members frequently intermarried with 
governors-general installed by the Sasanian king, often Armenian nobles, for two centuries. ${ }^{41}$

Quantitatively and qualitatively, the most influential amongst the Iranian languages in contact with Armenian was Parthian, ${ }^{42}$ spoken by the members of the Arsacid dynasty that ruled Armenia for about four centuries. ${ }^{43}$ The number of lexical borrowings from Parthian and its sister language Middle Persian can rival that of directly inherited Indo-European words, ${ }^{44}$ and includes not only cultural and non-core lexicon, but extends into closed classes like numerals and prepositions, and the core vocabulary. ${ }^{45}$ Table 1 offers a few examples.

TABLE 1 Some Iranian loanwords in Armenian

\begin{tabular}{lll}
\hline & Arm. & Pth. \\
\hline 'army' & zawr & \\
'field' & dašt & z'wr /zāwar/ \\
'root' & bun & dšt /dašt/ \\
'black' & seaw & sy'w / syāw/ \\
'white' & spitak & spyd /ispēd/ \\
'to recline' & bazmim & bzm /bazm/ \\
'to order' & hramayem & frm'y- /framāy-/ \\
'1,ooo' & hazar & hz'r /hazār/ \\
'because of' & vasn & wsn'd /wasnāo/46 \\
& & \\
\hline
\end{tabular}

Persian royalty (cf. Xenophon, Anabasis 2.4.8, 3.4.13, 4.4.4); nonetheless, it is evident that this dynasty was originally of Iranian, not Armenian origin (cf. Manandian, 1965: 36-8; Toumanoff, 196o; 1963: 277-305; 1969; Garsoïan, 1997a).

41 More information on the history and government of marzpanate Armenia can be found in Garsoïan (1997c).

42 The fact that Parthian, i.e. a North-Western Middle Iranian language, was the primary source of the Armenian loanwords was established first by Meillet (1911-12).

43 For a fuller history of early Armenia, see Garsoïan (1997a,b).

44 According to the statistics of Belardi (2003: 98-102), 35 per cent of the lexical material contained and etymologically analysed in Hübschmann (1897) is of Middle Iranian origin, while only 22 per cent is echtarmenisch, i.e. of direct Indo-European heritage. Hübschmann's data is, of course, out-dated and in part erroneous, but not to such an extent that this proportion would shift entirely.

45 While Table 1 includes a few words that occur also in the Swadesh list (Swadesh, 1971: 293), core lexicon is here taken in its wider sense to include items of everyday relevance in general.

46 While it is clear that Arm. vasn is of Iranian origin, its precise derivation is difficult to determine, since neither Pth. wsn'd, nor MP wšn, nor OP vašnā fit the bill precisely. 
Apart from the lexicon, Parthian had considerable influence on the derivational morphology and phraseology of Armenian. This includes the formation of denominal adjectives and patronymics, a number of nominal and verbal affixes, calques and semi-calques of both nominal compounds as well as complex predicates. ${ }^{47}$ Recent studies further suggest that Armenian syntax has also been affected by Iranian patterns; in particular, this includes the expression of reflexive relations and the function of anaphoric pronouns and intensifiers. ${ }^{48}$

Another instance of pattern replication has been recognised in the unusual morphosyntactic alignment of the periphrastic perfect. As an Indo-European language, all synthetic tenses of Armenian construe according to nominativeaccusative alignment: ${ }^{49}$ intransitive subjects (S) and transitive agents (A) receive the same morphological marking (nominative), whereas objects $(\mathrm{O})$ are marked differently (accusative). ${ }^{50}$ This pattern is illustrated in $(7-9)$ below.

\section{(7) Classical Armenian (PB ini.3)}

\begin{tabular}{|c|c|c|c|}
\hline$z=$ aynu & žamanakaw & ert'eal & hasanèr \\
\hline about=DEM.INS.SG & time.INS.SG & go.PTCP & arrive.3.SG.PST \\
\hline episkoposapet $=n$ & Vrt'anēs & & \\
\hline archbishop.NOM.SG=DET & $\mathrm{PN}$ & & \\
\hline
\end{tabular}

47 Semi-calques refer to instances where part of a nominal compound or complex predicate has been translated from the source language, whilst another part remains in its original form, e.g. Arm. č́arabaxt 'unfortunate', cp. MP wtb'ht /watbāxt/ 'id.', where čar- is an Armenian translation of MP $w t$ /wat/ 'bad'.

48 See Meyer (2013); the Armenian pronoun ink' $n$ '-self' is shown to be used both as intensifier and anaphoric pronoun with a functional distribution very close to that of Pth. wxd, MP xwd 'id..'

49 Armenian distinguishes three synthetic tenses (present, imperfect, aorist), each occurring in two voices (active and medio-passive). Present and aorist form three moods (indicative, subjunctive, imperative); forms of the subjunctive are used to express future actions. Next to these, there are two analytical tenses (perfect, pluperfect), formed with the past participle and a copulative verb in the present or imperfect. A strict differentiation along lines of aspect does not occur.

50 Although Armenian does not distinguish nominative and accusative singular in the nominal paradigm, a distinction does exist in the plural and in some personal pronouns. Relatively consistent differential object marking (DOM) through a proclitic Arm. $z=$ further allows for the distinction of otherwise unmarked forms. 
(8) Classical Armenian (PB iII.3)

$\begin{array}{llll}\text { isk eraneli }=n & \text { Vrt'anès } & z=\text { ban }=n & \text { vardapetut' } e a n=n \\ \text { CONJ blessed }=\text { DET } & \text { PN } & \text { OBJ }=\text { word.ACC.SG }=\text { DET } & \text { learning.GEN.SG }=\text { DET }\end{array}$

$i \quad$ mej arnuyr

in middle receive.3.SG.PST

'And the blessed Vrt'anēs cited (lit. received amidst) the Word of Learning in [...]'

(9) Classical Armenian (Eł. iI.55)

ew gundsgunds darjeal gumarēin $i$ noc'anē

CONJ many again summon.3.PL.PST by 3.ABL.PL

$y=$ erkir herawor

into=land.ACC.sG remote

'And again many of them were summoned by them to a remote land'

Examples (7-9) show, respectively, an active one-place predicate, a two-place predicate, and a passive one-place predicate with the demoted agent expressed in a prepositional phrase. This configuration is the standard in all tenses, and continues to be so in the modern Armenian daughter languages.

Conversely, a different, and typologically less wide-spread, alignment pattern is employed in the periphrastic perfect, which is construed with a passiveintransitive participle ${ }^{51}$ and optionally with a form of the verb em 'to be' or similar copulative verbs. With one-place predicates, the periphrastic perfect shows the same nominative-accusative type pattern already seen in other tenses $(10-11)$.

(10) Classical Armenian (Eł. iII.211)

ew k'anzi žamanak jmeraynwoy haseal èr

CONJ because time.NOM.sG winter.GEN.SG arrive.PTCP be.3.sG.PST

'And because the time of winter had arrived'

(11) Classical Armenian (PB ini.13)

\begin{tabular}{|c|c|c|c|c|}
\hline apa & barjeal & t'oteal & eten & nok'a \\
\hline $\mathrm{CONJ}$ & raise.PTCP & forgive.РTCP & become.3.PL.AOR & 3.NOM.PL \\
\hline jeranē & tearn & & & \\
\hline hand.ABL.SG & lord.GEN.SG & & & \\
\hline
\end{tabular}

'And they were elevated and forgiven by the hand of the Lord'

$5^{1}$ The semantics of the participle have been a matter of debate for some time; for the most recent argument in favour of an original passive-intransitive reading, see Meyer (2014; 
In each instance, so far, the subject has been found in the nominative, whereas an object, where present, showed accusative marking. In the transitive periphrastic perfect, however, the agent of the verb is expressed in the genitive, while the object remains in the accusative; the copula, where it occurs, is exclusively in the 3.SG.

(12) Classical Armenian (Eł. IV.50)

$\begin{array}{lllll}\text { bac }^{\prime} & y=a y n c^{\prime} & \text { Hnac', } & \text { oroc' }^{\prime} & \text { ban-s } \\ \text { except } & \text { from=DEM.GEN.PL } & \text { Hun.GEN.PL } & \text { REL.GEN.PL } & \text { word-ACC.PL } \\ \text { edeal } & \bar{e} \text { r. } & & \\ \text { give.PTCP } & \text { be.3.SG.PST } & & \\ \text { 'except for these Huns, who had given their word.' } & \end{array}$

(13) Classical Armenian (Eł. III.53)

$\begin{array}{llllll}\text { loweal } & i s k & \bar{e} r & i m & i & \text { naxneac' } \\ \text { hear.PTCP } & \text { CONJ } & \text { be.3.SG.PST } & \text { 1.GEN.SG } & \text { from } & \text { ancestor.GEN.PL } \\ \text { meroc' } & e t^{\prime} \bar{e} & & & & \end{array}$

1.PL.POSS.GEN.PL COMP

'And I have heard from our ancestors that $[\ldots]$ '

In the periphrastic perfect, therefore, Classical Armenian shows tripartite alignment, with different morphological marking of intransitive subject, transitive agent, and object. This type of alignment is cross-linguistically rather uncommon; it is synchronically stable in some languages such as Yazgulyami (Indo-Iranian, Pamir; cf. Payne, 1980), some dialects of Pahari and Western Hindi (Indo-Aryan; Stroński, 2010; also cf. Liljegren, 2014: 15off.), and frequently appears to be a transitional stage from ergative-absolutive to nominativeaccusative alignment (Skalmowski, 1974; Payne, 1980: 150). In a third set of languages, tripartite alignment occurs next to other alignment types in a split system; in Armenian, this split is tense-based, whereas Wanggumara, WagaWaga, Yidiny, and Dyirbal exhibit an animacy-based alignment split (cf. Blake, 1977: 11; Dixon, 1979: 86-8).

While attempts at explaining the construction of the periphrastic perfect have been made since at least the beginning of the $20^{\text {th }}$ century with Meillet (1903), no single approach has gained the acceptance of all scholars and explained the construction fully. ${ }^{52}$ Where internal reconstruction alone is

2017: 70-82); for a different perspective on a 'diathesenindifferentes' participle, see Stempel (1983).

52 Meillet suggested that the genitive subject was due to the originally nominal nature of the participle, wherefore a statement such as Arm. nora bereal $\bar{e}$ 'he has carried' would be the 
insufficient, a contact-based explanation must be considered (Poplack and Levey, 2010). Consequently, the unusual alignment of the Armenian periphrastic perfect may be based on pattern replication from Western Middle Iranian, specifically Parthian, which construes its participle-based past tense along ergative-absolutive lines. ${ }^{53}$ As the Parthian examples (14-15) below show, ergative alignment is not only marked on pronominal constituents, but also on the copula, which in the past tense agrees with the object.

(14) PARThiAn (MKG 1398-1400)

byc 'w's $c y=m$ dyd 'yy tw sxwn

CONJ now $\mathrm{COMP}=1 . \mathrm{SG}$ see.PTCP be.2.SG.PRS $\mathrm{CONJ=1.SG} \mathrm{2.SG} \mathrm{speech}$

'šnd

hear.PTCP

'And now that I have seen you and heard your speech'

(15) Parthian $\left(\mathrm{M}_{42} / \mathrm{R} / \mathrm{i} / 14-16\right)$

qd $t w \quad$ 'br sd 'yy 'w=t 'z

CONJ 2.SG upwards go.PTCP be.2.SG.PRS CONJ=2.SG 1.SG.DIR

hyšt hym syywg

leave.PTCP be.1.sG.PRs orphan

'When you ascended and left me an orphan'

Evidently, the Parthian pattern has not been replicated in Armenian without change, since Armenian shows not ergative, but tripartite alignment. The difference between the two systems manifests itself in the marking of the object as accusative in Armenian, as opposed to the direct case in Parthian, which given its other functions should be rendered as an Armenian nominative.

A likely explanation for this alteration of the replicated pattern lies in differential object marking, whereby only definite accusative objects are prefixed with Arm. $z=$. This marking system, it appears, was extended to include logical

equivalent of 'there was his carrying' (1936 [1903]: 128-9); this, however, raises the question why intransitive verbs do not construe similarly (cf. e.g. Deeters, 1927: 80). A later suggestion of Benveniste's (1952) analyses the periphrastic perfect as a 'have'-perfect, pointing out similarities to the Old Persian taya mana krtam construction. For refutations of this and other approaches, see Meyer $(2016,2017)$.

53 In the latest stages of their attestation, Western Middle Iranian languages distinguish a direct case and an oblique case only in the pronominal paradigm, otherwise relying on prepositional object marking and word order (Durkin-Meisterernst, 2014: 262-3, 330-40). Earlier stages did, however, have a more refined case system (Skjærvø, 1983; DurkinMeisterernst, 2014: 198-203). Ergative alignment is further evident since the copula agrees with the object. 
next to grammatical objects, and thus contributed to the establishment of an accusative object case in the periphrastic perfect. Without a doubt, this process was aided by the fact that in the singular, nominative and accusative cannot be differentiated morphologically, making easier a reinterpretation of an old nominative as a new accusative. (16) is an example of such an old pattern, in which the object is unmarked; such instances are, however, not frequent in the extant texts. ${ }^{54}$

(16) Classical Armenian (Ag. 766)

\begin{tabular}{|c|c|c|c|}
\hline ard & areal & $t^{\prime}$ agawor- $i=n$ & p'aytat \\
\hline $\mathrm{CONJ}$ & take.PTCP & king-GEN.SG=DET & axe.NOM/ACC.SG \\
\hline bah, & hatanēr & $z=\operatorname{dir}-s$ & \\
\hline spade.NOM/ACC.sG & cut.3.SG.PST & $\mathrm{OBJ}=$ place $-\mathrm{ACC} . \mathrm{PL}$ & \\
\hline
\end{tabular}

While this is not the only adaptation that the Parthian pattern underwent in Armenian, it is by far the most significant, ${ }^{55}$ since it results in alignment change. Classical Armenian, under the influence of Western Middle Iranian languages, has developed a tense-sensitive alignment split, with nominativeaccusative alignment in all tenses except for the periphrastic perfect. The genesis of this split unfortunately predates extant historical documents, wherefore all analyses rely on remnants of previous stages in the attested texts.

While this alignment split is synchronically stable in the earliest Classical Armenian texts $\left(5^{\text {th }}\right.$ century CE), it shows a certain amount of anomalous variation already in early texts, and by the $8^{\text {th }}$ century has largely shifted towards nominative-accusative alignment across all tenses. ${ }^{56}$ The anomalies in

54 Other occurrences often include an indefinite pronoun Arm. mi. Unmarked objects more regularly occur as part of complex predicates, e.g. in Arm. skizbn ainel 'to make a beginning'.

55 Other differences include the generalisation of an optional 3.SG copula for all persons, whereas Parthian shows copula forms agreeing with the object for $1 / 2.5 G$, and no finite verb for 3.sG. Further, the choice of the genitive as the agent case, corresponding to the Parthian oblique case, is not self-evident. For a discussion of these problems, see Meyer (2016, 2017).

$5^{6}$ Cf. Weitenberg (1986: 15); it is of note that in the sources languages, Parthian and Middle Persian, split-ergative alignment is also ousted by the dominant nominative-accusative pattern in the late stages of their development (Durkin-Meisterernst, 2014: 398-400). While typologically similar, it is unlikely for historical reasons that this development is the basis of changes in Armenian. 
question are all indications of the volatility of the minority alignment pattern of the periphrastic perfect: on the one hand there are nominative agents in transitive contexts (where genitive would be expected; 17), on the other hand, genitive agents with intransitive verbs (where a nominative would be expected; 18).

(17) Classical Armenian (PB iil.5)

$\begin{array}{llllll}\text { ew } & z=\text { ays } & \text { amenayn } & \begin{array}{l}\text { loweal } \\ \text { hear.PTCP }\end{array} & \begin{array}{l}\text { manuk=n } \\ \text { youth=DET }\end{array} & \begin{array}{l}\text { Yusik } \\ \text { PONJ }\end{array} \\ i & \text { OBJ=DEM.ACC.SG } & \text { all } & & & \\ \text { from } & \text { angeltakèn } & & & & \end{array}$

'And the youth Yusik heard all this from the angel'

(18) Classical Armenian (EK II.16.165)

$\begin{array}{lllll}\text { kamēr } & t ' \bar{e} & \check{c}^{\prime}=\bar{e} r & \text { yanc'uc'eal } & \text { Adam-ay } \\ \text { wish.3.SG.PST } & \text { COMP } & \text { NEG=be.3.SG.PST } & \text { sin.PTCP } & \text { PN-GEN.SG } \\ \text { 'He wished that Adam had not sinned.' } & & \end{array}$

The use of the genitive with an intransitive verb in the periphrastic perfect lends further credence to the suggestion that this was a replicated rather than an inherited pattern, wherefore confusion concerning its usage arose on occasion. In turn, the extension of the nominative to work as the agent even in the active is likely the result of both system pressure from other tenses, and the fact that, when coordinated with other, nominative-accusative aligned tenses, the perfect does not require the agent to be restated in the genitive. ${ }^{57}$ Thus arise contexts in which the grammatical subject of the perfect is legitimately in the nominative.

The example of the Classical Armenian periphrastic perfect therefore shows in two instances the influence of typological distance on the development of replicated patterns in the replica language: firstly, the replicated ergative alignment pattern of Western Middle Iranian was, in all likelihood, initially adopted without change. ${ }^{58}$ By the time of its first attestation, however, the pattern had

57 That is to say, in analogy to the usage in ergative languages, that the tripartite alignment of the perfect is only morphological, not syntactic, viz. coreferential constituents may be omitted no matter the alignment pattern associated with the verbs of the different clauses (cf. Dixon, 1994: 143).

$5^{8}$ This has to remain a speculative assumption, since no data from the time in question is available; residual ergatively aligned patterns and usages in Classical Armenian, with genitive agents and unmarked nominative objects, speak in favour of this reconstruction. 
already undergone mutations, marking the object as accusative like in all other tenses. ${ }^{59}$ Secondly, this adapted pattern was maintained as long as there was significant contact with the model language, but with the subsiding of the Sasanians' political dominance as a result of the Arab conquest, this ceased to be the case in the middle of the $7^{\text {th }}$ century. The minority alignment pattern of the perfect then gave way to the systemic pressure from other tenses, resulting in a change to nominative-accusative alignment. ${ }^{60}$

These findings align neatly with the parameters suggested above. As opposed to the case of Old Aramaic above, the replicated pattern in Classical Armenian was of significant centrality from the beginning, being one of the main narrative tenses and occurring with great regularity in all text types. Like in the other languages mentioned or discussed, supposed constraints relating to typological distance have not prevented the initial replication of this pattern; instead, systemic pressures owed to typological differences within the Armenian verbal system have resulted in the adaptation of the replicated pattern to the replica language, and later in the levelling of all differences through the adoption of the standard alignment pattern. The latter stage of this process coincides with major socio-historical changes, owing to which the previous level and kind of contact with the model language was no longer maintained or desired, and bilingualism likely subsided.

While the metatypical change that Classical Armenian underwent did not result in full metatypy in the sense of alignment change across the whole verbal system, it clearly demonstrates that issues of consistency or typological differences, together with centrality or frequency of use, and constancy, that is socio-historical concerns, play a role in the retention of replicated patterns in language contact situations, rather than in their initial inception.

59 The use of a 3.sG copula is likely an Armenian-internal development, resulting from pressure to make all perfect forms fully inflected for person and number; given that verbal agreement neither with an object nor a genitive case constituent is found or licensed elsewhere in Armenian, an impersonal form was used. A similar situation obtains in other languages with split alignment, e.g. Hindi and Talyši (Payne, 1979: 442; Pirejko, 1966); Comrie (1978: 342) suggests that such invariant forms are an indicator of alignment change in progress.

6o The language of the Sasanians, Middle Persian, was of course not strictly speaking the model language, but uses an almost identical pattern. West Middle Iranian also loses its ergative alignment pattern (cf. Durkin-Meisterernst, 2014: 398-400), but owing to the nature of the documents, this development is difficult to date. Even supposing an early loss of ergative alignment, however, the point still holds: a lack of contact with the model pattern, whether owing to changes in the contact situation or loss of said pattern, results in the loss of a factor that supports the typologically different pattern. 


\subsection{The NENA simple past and Sulaymaniyah Kurdish}

While the languages of antiquity and the Middle Ages present certain problems as regards studies of their socio-linguistic history (lack of documentation; limited genres; socially non-diverse authorship; etc.), that of the various modern dialects of North-Eastern Neo-Aramaic (NENA) is more readily accessible in this respect. Yet, as Noorlander remarks

"the Kurdish and Aramaic speech communities maintain highly complex historical relationships, of which much is still obscure and perhaps will remain forever so. The wide range of sociolinguistic factors involved obviously shifted and drifted over the course of time, yet it is safe to say contact between the two continued without interruption." (Noorlander, 2014:203).

While contact between the two language families stretches more than 2,500 years, not all sources useful for the consideration of modern dialects go back quite as far, with the onset of some contact situations datable only to the $18^{\text {th }}$ century.

The results of language contact differ in each dialect, but may include any of the whole plethora of possibilities. Khan $(2004,2007)$ illustrates a number of borrowings into NENA from Kurdish dialects, including phonological changes (e.g. postvocalic [t⿱țn] ], [ $\mathrm{d}]$ ] > [l] in bela < *beta, cp. OA byt /bayit/ 'house' or 'ile < *'ide, cp. OA yd /yad/ 'hand'; cf. Mutzafi, 2004: 36-8) and loss of grammatical categories (e.g. loss of gender in the pronouns). For the present purpose, however, it is the construction of the simple past (perfective) in the Judaeo-Aramaic dialect of Sulaymaniyah in Iraqi Kurdistan that is of most interest.

The vast majority of the Muslim population of the town, founded in 1784 , speaks a dialect of Central Kurdish (Sorani); the Jewish community, most of whom came from a village some twenty miles away, used this local dialect to communicate with their neighbours until the community emigrated to Israel between 1950 and $195^{2}$ (cf. Khan, 2007: 198). This form of NENA is now only spoken by a few surviving community members in Jerusalem.

Sulaymaniyah Kurdish has a tense-sensitive split-ergative inflection pattern, wherein tenses based on the past stem exhibit ergative marking, while all other tenses follow a nominative-accusative pattern (cf. Khan, 2004: 10-11). ${ }^{61}$

61 Sulaymaniyah Kurdish shows nominative-accusative alignment in all tenses, but has preserved ergative inflection as shown in Table 2 (cf. Bynon, 1979: 215-7, 1980: 154-8; Jügel, 2009). It is noteworthy, that Kurmanci Kurdish is in the process of losing its ergative marking (Dorleijn, 1996). 
TABLE 2 Alignment Pattern of Sulemaniyya Kurdish

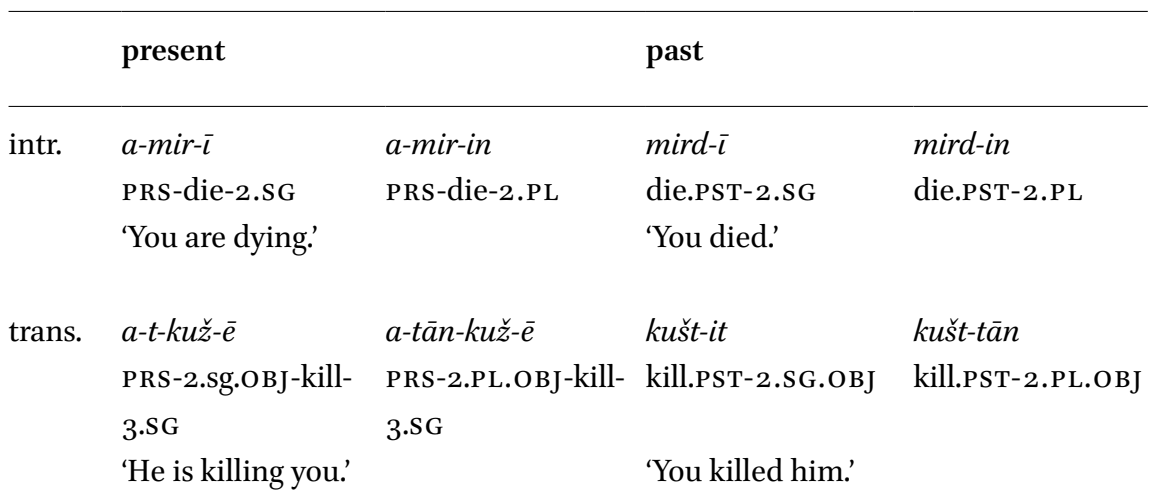

This is similar to the pattern found in Middle Persian and Parthian illustrated above. Thus, intransitive verbs behave in like fashion in the present and simple past, but transitive verbs diverge significantly, as Table 2 illustrates. ${ }^{62}$

In the present and past intransitive, a clitic is added to the verb, agreeing with the subject. For the transitive verb, a subject clitic of the same type is affixed to the verb in the present; an object clitic precedes the verb. In the transitive past, however, this object clitic fills the subject position, following the verb; a subject clitic (Ø for 3.SG) may further be added. Evidently, then, it is the form (or case) of the clitic that suggests ergative alignment, rather than its position, which may vary.

This pattern is reflected in NENA, as shown in Table 3 and (19-20).

(19) North-Eastern Neo-Aramaic (Jewish Sanandaj; Doron and Khan, 2012:227) baxt-ăke barux-ăwal-i garš-á-lu

woman-DE F

friend-PL-1.SG.POSS pull.PRS-3.SG.F.DIR $\mathrm{A}^{-3}$.PL.OBL $\mathrm{O}$

'The woman pulls my friends.'

62 This analysis is, of course, simplified. In the past transitive, the agent marker attaches to the first word within VP; further clitics, e.g. marking the object, may occur and subsequently attach to the verb (cf. Haig, 2008: 288-296). 
TABLE 3 Alignment Pattern in SulaymaniyahJudaeo-Aramaic

\begin{tabular}{|c|c|c|c|c|}
\hline & present & & past & \\
\hline intr. & $\begin{array}{l}\text { mel-et } \\
\text { die.PRS-2.SG } \\
\text { 'You are dying.' }\end{array}$ & $\begin{array}{l}\text { mel-etun } \\
\text { die.PRS-2.PL }\end{array}$ & $\begin{array}{l}\text { mïl-et } \\
\text { die.PST-2.sG } \\
\text { 'You died.' }\end{array}$ & $\begin{array}{l}\text { mīl-etun } \\
\text { die.PST-2 PL }\end{array}$ \\
\hline trans. & $\begin{array}{l}\text { qățil-lox } \\
\text { kill.PRs-2.sG.OBJ } \\
\text { 'He is killing you.' }\end{array}$ & $\begin{array}{l}\text { qătil-laxun } \\
\text { kill.PRS-2.PL.OBJ }\end{array}$ & $\begin{array}{l}\text { qțil-lox } \\
\text { kill.PST-2.SG.OBJ } \\
\text { 'You killed him.' }\end{array}$ & $\begin{array}{l}\text { qțil-laxun } \\
\text { kill.PST-2.PL.OBJ }\end{array}$ \\
\hline
\end{tabular}

(20) North-Eastern NeO-Aramaic (Jewish Sanandaj; Doron and Khan, 2012: 228) baxt-ăke barux-ăwal-i garš-íla

woman-DEF friend-PL-1.SG.POSS pull.PRS-3.PL.DIR $\mathrm{O}^{-} 3$. SG.F.OBL

'The woman pulled my friends'

This pattern mirrors the Kurdish model, and is not dissimilar to the one found in Old Aramaic and Syriac mentioned in section 4.1; the (marginal) preexistence of the classical pattern may well have been a factor in the replication of the present pattern into NENA.

The Sulaymaniyah NENA pattern is not an exact copy of the Kurdish model, of course, but shows the same formal symmetry of present object and past agent taking the same clitic form. Whilst clitics in the Kurdish dialects may appear separated from the verb, their position is fixed in NENA, but their grammatical function as agreement markers is tense-dependent.

Nonetheless, the NENA verbal system has been affected to such an extent by Sulaymaniyah Kurdish that the morphosyntactic alignment of the simple past tense and the order and meaning of the associated affix system no longer correspond to that of the rest of the verbal system. This contact-induced splitergative alignment, which goes beyond the changes described for Syriac and Old Aramaic, clearly shows metatypical changes that may lead to systemic alignment change.

The construction has been fairly stable in NENA owing to its frequency in speech and prolonged contact with the Kurdish dialects. Yet, like in many split-ergative languages, system pressure from the present tense has resulted in compromise constructions such as (21): 
(21) North-Eastern Neo-Aramaic (Jewish Sulaymaniyah; Khan, 2004: 12) qțil-le 'illox kill.PST-3.SG.M.OBL 2.SG.OBL $L_{O}$ 'He killed you.'

In this example, both agent and patient are represented by oblique case forms, with the object no longer attached to the verb as a clitic, reminiscent of the outcome of the qțil $l$ - construction in Syriac. Instead, a prepositional phrase with an enclitic pronoun is used, particularly in 1.SG and 2.SG patients. The expected form, with the patient of the past transitive verb suffixed to the verb in direct case, preceding the oblique-case agent marker, is given in (22):

(22) North-Eastern Neo-Aramaic (Christian Barwar; Doron and Khan, 2012: 229)

Peni qtil-a-le Pay-baxta

who.sG.M kill.PST-3.SG.F.DIR O-3.SG.M.OBL $_{\mathrm{A}}$ DEM-woman

'Who killed that woman?'

The argument order in (21) has, therefore, been adapted to that of the present tense system, with agent marker followed by object marker, albeit with morphological forms diverging from the present. ${ }^{63}$

The format shown in (21) is, as regards sequence of constituents, an accommodation of the past-tense system in favour of the more widely used present tense order. The replicated split-ergative system is being eroded by system pressure to conform to the predominant nominative-accusative pattern found in other tenses. Similar changes are, of course, also found in languages whose split-ergative pattern does not derive from language contact. ${ }^{64}$

Recent research (Doron and Khan, 2012; Barotto, 2014) concerning NENA dialects shows, however, that more than one path can lead to de-ergativisation. In some dialects of NENA, such as the Judaeo-Aramaic of Sanandaj and Urmia, ergative marking in the simple past has spread to intransitive verbs, now

63 Khan (2007: 204-5) notes that the spread of ergative alignment in the tenses of NENA differs vastly between dialects; while the Sulaymaniyah dialect is in the process of losing its ergative pattern in the simple past, other dialects, such as that of Sanandaj and Kerend, further show this marking pattern in the compound past. The same distribution is found in the relevant Kurdish dialects.

64 The case of Western Middle Iranian has been mentioned above, section 4.2. 
applying to unergative ${ }^{65}$ verbs in the former and to all intransitives in the latter. ${ }^{66}$ This type of development is not paralleled in any of the closely related Kurdish dialects (Khan 2008: 21) ${ }^{67}$ Barotto (2014: 93) concludes that, in one form or another, all NENA dialects are in the process of restructuring the alignment of the perfective past to fit the nominative-accusative pattern of the imperfective system.

\section{5} Centrality, Constancy, and Consistency - a Conclusion

While it remains impossible to predict precisely which patterns of a model language might be adapted into a replica language in a sufficiently intense and long-term contact situation, it has been established that anything is possible in principle. Typological distance of whatever degree does not affect the 'borrowability' of patterns (although it may affect in which direction such replications develop).

It is a separate question altogether, however, whether a model language pattern that has been employed by a bilingual speaker of both languages will spread in the replica language or not. Three separate factors play into the promulgation and maintenance of patterns: their centrality in the grammar of the bilingual speaker, the constancy of contact with the model language or of bilingualism, and their typological consistency with the replica language systems affected. In the three cases discussed above, it has been shown that the absence or decline of any of these factors is the, or one of the, underlying factor(s) in the loss or adaptation of replicated structural patterns.

In the case of the qtil $l$ - construction of Old Aramaic, the replicated verbal pattern did not form part of, replace, or add to existing verbal paradigms, but has remained a minority construction. Lacking frequent use, even constant

65 Some languages divide their intransitive verbs into two types, unergative and unaccusative. The difference between the two types lies in the semantics of the subject: those of unergative verbs exact control over the action denoted by the verb (to run, to work), whereas unaccusative verbs have more patient-like, non-volitional subjects (to fall, to die). The split between the two types need not be lexically fixed, however (cf. Dixon, 1994: $70-78)$.

66 In the Urmia dialect, the old absolutive pattern may still be used to denote a stative past.

67 The Gorani dialect Bājalānī, however, has also generalised this marking pattern (cf. MacKenzie, 1956: 421-2). 
contact and the relative typological consistency ${ }^{68}$ were unable to maintain or foster this pattern. It gained currency only with its adaptation to the more common alignment pattern of the other tenses in Syriac.

The situation in Classical Armenia shows variation already in the early stages of the language's attestation, but the decline of the tripartite periphrastic perfect coincides rather closely with the decline of the Western Middle Iranian languages as a vehicle of cultural and political dominance in the area. The ensuing loss of proficiency in these languages resulting from lacking constancy of contact and bilingualism then allowed for an adaptation of the perfect alignment pattern in order to match the other tenses, thus improving cross-system harmony and typological consistency. For Armenian, therefore, the centrality of the periphrastic perfect in (at least) literary usage and the centuries-long contact and bilingualism with the model language have to some degree acted as a blocking mechanism against adaptation to the mainstream alignment pattern.

The most complicated case is that of NENA dialects. Evidently, even under maintenance of constant language contact and concomitant bilingualism, an adjustment of patterns contravening the norm may occur. The different ways in which NENA dialects adapt their replicated ergative past tenses to the dominant nominative-accusative pattern show clearly that there is more than one way of dealing with differences in alignment patterns. It shall remain open here whether lack of typological consistency, and therefore system pressure alone is responsible for this particular change. ${ }^{69}$

Centrality and constancy, it appears then, may to some extent act as blocking mechanisms in the typological adaptation of model language patterns to the replica language. As long as replicated patterns are used frequently enough, and speakers continue to be sufficiently proficient bilinguals so that the same underlying pattern is indeed accessed in speech acts in both languages, the concepts of centrality and constancy may counterbalance the potentially diametrically opposed 'pull' exerted by the strive for typological consistency. ${ }^{70}$

68 Since Old Aramaic and Syriac do have other constructions in which an agent is expressed by means of a prepositional phrase (see section 4.1 above), the typological distance of this pattern to the norm is minimal.

69 It is entirely conceivable that the precise relationship between the contact languages may have changed without loss of contact; imperfect bilingualism, diglossia, and community size are some of the components that, as part of the concept of constancy, may further influence the maintenance of typologically diverse patterns.

70 This refers to alignment changes in particular; adaptations concerning the morphological realisation of replicated patterns may be necessary in cases where replica and model language do not have corresponding categories. 
The precise determination of this balance, however, is made difficult by the lack of quantifiability of typological distance; while the centrality of a pattern may be measured as its relative frequency when compared to similar patterns, and Constancy is a function of the number of bilingual speakers over time, no non-abstract and non-arbitrary number is readily associated with typological concepts such as morphosyntactic alignment.

Further research into language contact situations which provide sufficient diachronic depth in order to account for the variables in question here will show whether the role of centrality, constancy, and consistency for the maintenance of replicated patterns suggested here is viable as is, or requires further refinement. Such cases should be of particular interest as show metatypical changes or full-blown metatypy, in the hope that closer observations and analyses will be able to determine whether metatypy is triggered or conditioned by any specific factors not present in cases of mere metatypical changes. The application of statistical analysis to the diachronic development of such patterns together with census data and other speaker-related information will likely prove central to this endeavour. While it remains impossible to predict with any certainty which patterns will be replicated in language contact situations in the first instance, it is hoped that the above discussion provides an impetus for further study concerning the post-replication fate of such patterns.

\section{Acknowledgements}

A preliminary version of this paper was presented in November 2015 at TypoUlm in Paris; I am grateful to Gilles Authier for the invitation and his comments. I would further like to thank Elizabeth Tucker, Theo Maarten van Lint, and Wolfgang de Melo for their thoughts and suggestions on drafts of this paper, and the three anonymous reviewers and editors of the JLC for their corrections and constructive criticism. All errors and omissions are, of course, mine.

\section{Bibliographical Abbreviations}

$\begin{array}{ll}\text { Ag. } & =\text { Agat’angełos, History of Armenia (Thomson 1980) } \\ \text { am } & =\text { Acta martyrum et sanctorum (Bedjan 1968) } \\ \text { DB } & =\text { Inscription of Darius I at Behistun (Schmitt 1991) } \\ \text { Eł. } & =\text { Ełišē, History of Vardan and the Armenian War (Thomson 1993) } \\ \text { EK } & =\text { Eznik Kołbac'i, Refutation of Sects (Mariès and Mercier 1959) }\end{array}$




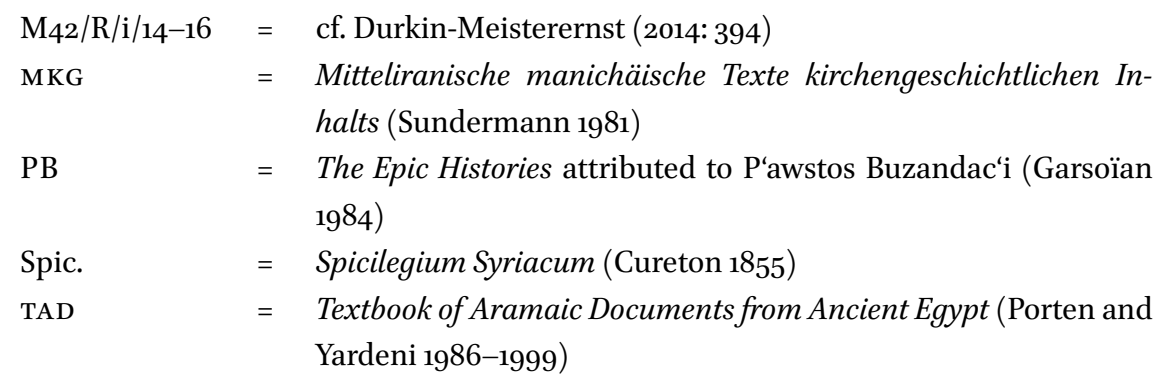

\section{References}

Aikhenvald, Alexandra Y., 2007. Grammars in Contact: A Cross-Linguistic Perspective. In Alexandra Y. Aikhenvald, ed., Grammars in Contact: A Cross-Linguistic Perspective, 1-66. Oxford: Oxford University Press.

Anderson, Stephen R., 1977. On Mechanisms by Which Languages Become Ergative. In Charles N. Li, ed., Mechanisms of Syntactic Change. Symposium on the Mechanisms of Syntactic Change, University of California, 1976, 317-363. Austin: University of Texas Press.

Barotto, Alessandra, 2014. Typology of case alignments in NENA dialects. RiCognizioni. Rivista di lingue, letterature e culture moderne 2(1): 83-94.

Bedjan, Paul, ed., 1968. Acta martyrum et sanctorum (7 vols.). Hildesheim: Olms.

Belardi, Walter, 2003. Elementi di armeno aureo, vol. I. Rome: Il Calamo.

Benveniste, Émile, 1952. La construction passive du parfait transitif. Bulletin de la Société Linguistique de Paris 48: 52-62.

Blake, Barry J., 1977. Case marking in Australian languages. Canberra: Australian Institute of Aboriginal Studies.

Brandenstein, Wilhelm and Manfred Mayrhofer, 1964. Handbuch des Altpersischen. Wiesbaden: Otto Harrassowitz.

Bynon, Theodora, 1979. The ergative construction in Kurdish. Bulletin of the School of Oriental and Africa Studies 42(2): 211-224.

Bynon, Theodora, 1980. From Passive to Active in Kurdish Via the Ergative Construction. In Elizabeth C. Traugott, ed., Papers from the 4th International Conference on Historical Linguistics, 151-163. Amsterdam: John Benjamins.

Campbell, Lyle and Martha C. Muntzel, 1989. The structural consequences of language death. In Nancy C. Dorian, ed., Investigating obsolescence: Studies in language contraction and death, 181-96. Cambridge: Cambridge University Press.

Cardona, George, 1970. The Indo-Iranian Construction mana (mama) krtam. Language $46,1-12$. 
Ciancaglini, Claudia A., 2008. Iranian Loanwords in Syriac. Wiesbaden: Dr. Ludwig Reichert.

Coghill, Eleanor, 2016. The rise and fall of ergativity in Aramaic: cycles of alignment change. Oxford: Oxford University Press.

Comrie, Bernard, 1978. Ergativity. In Winfred P. Lehmann, ed., Syntactic Typology. Studies in the Phenomenology of Language, 329-394. Sussex: Harvester Press.

Cureton, William, 1855. Spicilegium Syriacum: containing remains of Bardesan, Meliton, Ambrose and Mara bar Serapion. London: Francis and John Rivington.

Curnow, Timothy J., 2001. What language features can be 'borrowed'? In Alexandra Y. Aikhenvald, ed., Areal diffusion and genetic inheritance: problems in comparative linguistics, 412-436. Oxford: Oxford University Press.

Deeters, Gerhard, 1927. Armenisch und Südkaukasisch. Leipzig: Verlag der Asia Major.

Dixon, Robert M.W., 1979. Ergativity. Language 55(1): 59-138.

Dixon, Robert M.W., 1994. Ergativity. Cambridge: Cambridge University Press.

Dorleijn, Margreet, 1996. The decay of ergativity in Kurmanci. Tilburg: Tilburg University Press.

Doron, Edit and Geoffrey Khan, 2012. The typology of morphological ergativity in NeoAramaic. Lingua 122: 225-240.

Durkin-Meisterernst, Desmond, 2014. Grammatik des Westmitteliranischen (Parthisch und Mittelpersisch). Vienna: Verlag der Österreichischen Akademie der Wissenschaften.

Eckman, Fred R., 1977. Markedness and the contrastive analysis hypothesis. Language Learning 27(2): 315-330.

Emeneau, Murray B., 1962. Brahui and Dravidian comparative grammar. Berkeley/Los Angeles: University of California Press.

Frye, Richard N., 1955. Review of G. R. Driver 'Aramaic Documents of the Fifth Century B. C.' Harvard Journal of Asiatic Studies 18(3/4): 456-461.

Garsoïan, Nina, ed., 1984. Buzandaran patmut $i w n k^{c}=($ The epic histories $):$ also known as, Patmut'iwn Hayoc' (History of Armenia). Delmar, NY: Caravan Books.

Garsoïan, Nina G., 1997a. The Emergence of Armenia. In Richard G. Hovannisian, ed., The Armenian People from Ancient to Modern Times, vol. 1: The Dynastic Periods, from Antiquity to the Fourteenth Century, 37-62. New York: St Martin's Press.

Garsoïan, Nina G., 1997b. The Aršakuni Dynasty (A.D. 12-[180?]-428). In Richard G. Hovannisian, ed., The Armenian People from Ancient to Modern Times, vol. 1: The Dynastic Periods, from Antiquity to the Fourteenth Century, 63-94. New York: St Martin's Press.

Garsoïan, Nina G., 1997c. The Marzpanate. In Richard G. Hovannisian, ed., The Armenian People from Ancient to Modern Times, vol. 1: The Dynastic Periods, from Antiquity to the Fourteenth Century, 95-116. New York: St Martin's Press. 
Givón, Talmy, 1979. Prolegomena to any sane creology. In Ian F. Hancock, ed., Readings in creole studies, 335 . Ghent: Story-Scientia.

Greenberg, Joseph H., 1966. Some Universals of Grammar with Particular Reference to the Order of Meaningful Elements. In Joseph H. Greenberg, ed., Universals of Language: report of a conference held at Dobbs Ferry, New York, April 13-15, 73-113. Cambridge, MA: MIT Press.

Haig, Geoffrey L.J., 2008. Alignment Change in Iranian Languages - A Construction Grammar Approach. Berlin/New York: Mouton de Gruyter.

Harris, Alice C. and Lyle Campbell, 1995. Historical syntax in cross-linguistic perspective. Cambridge: Cambridge University Press.

Haspelmath, Martin, 2006. Against markedness (and what to replace it with). Journal of Linguistics 42(1): 25-70.

Heine, Bernd and Tania Kuteva, 2003. On contact-induced grammaticalization. Studies in Language 27(3): 529-572.

Heine, Bernd and Tania Kuteva, 2005. Language Contact and Grammatical Change. Cambridge: Cambridge University Press.

Heine, Bernd and Tania Kuteva, 2008. Constraints on contact-induced linguistic change. Journal of Language Contact 2: 57-90.

Henning, Walter B., 1963. The Iranian words in Ezra and Daniel. In Franz Rosenthal, ed., A Grammar of Biblical Aramaic, 58-59. Wiesbaden: Harrassowitz.

Hettrich, Heinrich, 1990. Der Agens in passivischen Sätzen altindogermanischer Sprachen. Göttingen: Vandenhoeck \& Ruprecht.

Hinz, Walther, 1975. Altiranisches Sprachgut der Nebenüberlieferungen. Wiesbaden: Harrassowitz.

Hübschmann, Heinrich, 1875. Ueber die stellung des armenischen im kreise der indogermanischen sprachen. Zeitschrift für vergleichende Sprachforschung auf dem Gebiete der Indogermanischen Sprachen 23(1): $5^{-49}$.

Hübschmann, Heinrich, 1897. Armenische Grammatik. 1. Theil: Armenische Etymologie. Leipzig: Breitkopf \& Härtel.

Jakobson, Roman, 1971. Selected Writings (vol. II). The Hague: Mouton.

Jakop, Tjaša, 2012. Use of dual in standard Slovene, colloquial Slovene and Slovene dialects. Linguistica 52(1): 349-362.

Jamison, Stephanie, 1979. The case of the agent in Indo-European. Die Sprache 25(2): 129-143.

Jügel, Thomas, 2009. Ergative Remnants in Sorani Kurdish? Orientalia Suecana $5^{8}$ : $142-158$.

Jügel, Thomas, 2010. On the Origin of the Ergative Construction in Iranian: Evidence from Avestan. In Maria Macuh, ed., Ancient and Middle Iranian Studies: Proceedings of the 6th European Conference of Iranian Studies, held in Vienna, 18-22 September 2007, 99-114. Wiesbaden: Harrassowitz. 
Jügel, Thomas, 2015. Die Entwicklung der Ergativkonstruktion im Alt- und Mitteliranischen. Eine korpusbasierte Untersuchung zu Kasus, Kongruenz und Satzbau. Wiesbaden: Harrassowitz.

Kaufman, Stephen A., 1997. Aramaic. In Robert Hetzron, ed., The Semitic Languages, 114-130. Abindgdon: Routledge.

Khan, Geoffrey, 2004. The Jewish Neo-Aramaic Dialect of Sulemaniyya and Halabja. Leiden/Boston: Brill.

Khan, Geoffrey, 2007. Grammatical borrowing in North-eastern Neo-Aramaic. In Yaron Matras, ed., Grammatical Borrowing in Cross-Linguistic Perspective, 197-214. Berlin: Mouton de Gruyter.

Khan, Geoffrey, 2008. The Neo-Aramaic Dialect of Barwar. Leiden/Boston: Brill.

Kutscher, Eduard Y., 1969. Two 'Passive' Constructions in Aramaic in the Light of Persian. In Proceedings of the International Conference on Semitic Studies, Jerusalem, 19-23July 1965, 133-151. Jerusalem: Israel Academy of Sciences and Humanities.

Kutscher, Eduard Y., 1970. Aramaic. In Th. Sebeok, ed., Current Trends in Linguistics VI: Linguistics in South West Asia and North Africa, 347-312. The Hague: Mouton.

MacKenzie, David N., 1956. Bājalānī. Bulletin of the School of Oriental and African Studies $18(3)$ : 418-435.

Manandian, Hakob, 1965. The Trade and Cities of Armenia in Relation to Ancient World Trade. Lisbon: Livraria Bertrand.

Mariès, Louis and Charles Mercier, eds., 1959. Eznik de Kotb: De Deo. Édition critique du texte arménien. Paris: Firmin-Didot.

Matras, Yaron, 2009. Language Contact. Cambridge: Cambridge University Press.

Matras, Yaron and Jeanette Sakel, 2007. Investigating the mechanisms of pattern replication in language convergence. Studies in Language 31(4): 829-865.

Mayer, Gerald L., 1973. Common Tendencies in the Syntactic Development of 'Two', 'Three', and 'Four' in Slavic. The Slavic and East European Journal 17(3): 308-314.

Meillet, Antoine, 1903. Esquisse d'une grammaire comparée de l'arménien classique. Vienne: Imprimerie des PP. Mékhitaristes.

Meillet, Antoine, 1911. Sur les mots iraniens emptruntés par l'arménien. Melanges de la Société Linguistique de Paris 17: 250-252.

Meillet, Antoine, 1921. Le problème de la parenté des langues. In Antoine Meillet, ed., Linguistique historique et linguistique générale, 76-101. Paris: Champion.

Meillet, Antoine, 1936. Esquisse d'une grammaire comparée de l'arménien classique. Vienne: Imprimerie des PP. Mékhitaristes.

Meyer, Robin, 2013. Armeno-Iranian Structural Interaction: The Case of Parthian wxd, Armenian ink'n. Iran and the Caucasus 17(4): 401-425.

Meyer, Robin, 2014. Remodelling the Historical Morphology of the Classical Armenian -eal participle. Banber Matenadarani 21: 385-398. 
Meyer, Robin, 2016. Morphosyntactic Alignment and the Classical Armenian Periphrastic Perfect. In Stephanie W. Jamison, ed., Proceedings of the 26th Annual UCLA Indo-European Conference: Los Angeles, October 24th and 25th, 2014, 117-133. Bremen: Hempen.

Meyer, Robin, 2017. Iranian-Armenian language contact in and before the 5 th century $C E$. An investigation into pattern replication and societal multilingualism. DPhil thesis, University of Oxford.

Mutzafi, Hezy, 2004. The Jewish Neo-Aramaic Dialect of Koy Sanjaq. Wiesbaden: Harrassowitz.

Myers-Scotton, Carol, 2002. Contact Linguistics: Bilingual Encounters and Grammatical Outcomes. Oxford: Oxford University Press.

Myers-Scotton, Carol and Janice L. Jake, 200o. Testing the 4-M model: An introduction. The International Journal of Bilingualism 4(1): 1-8.

Nöldeke, Theodor, 1904. Compendious Syriac Grammar. London: Williams \& Norgate.

Noorlander, Paul, 2014. Diversity in convergence: Kurdish and Aramaic variation entangled. Kurdish Studies 2(2): 201-224.

Payne, John R., 1979. Transitivity and Intransitivity in the Iranian Languages of the U.S.S.R. In P. R. Clyne, ed., The Elements: A Parasession on Linguistic Units and Levels, April 20-21, 1979, including Papers from the Conference on Non-Slavic Languages of the USSR, April 18, 1979, 436-447. Chicago: Linguistic Society.

Pennacchietti, F., 1988. Verbo neo-aramaico e verbo neo-iranico. In Vincenzo Orioles, ed., Tipologie della convergenza linguistica. Atti del Convegno della Società Italiana di Glottologia, 93-110. Pisa: Giardini.

Pirejko, L.A., 1966. Талышский Язык. In V. V Vinogradov, ed., Языки Народов СССР. Индоевропейские языки, 302-322. Москва: Академия Наук сссР, Институт Языкознания.

Poplack, Shana and Stephen Levey, 2010. Contact-induced grammatical change: a cautionary tale. In Peter Auer, ed., Language and Space: An international handbook of Linguistic variation, vol. 1, Theories and Methods, 391-419. Berlin: De Gruyter Mouton.

Porten, Bezalel and Ada Yardeni, 1986-1999. Textbook of Aramaic Documents from Ancient Egypt. Winona Lake, IN: Eisenbrauns.

Rice, Keren, 2003. Featural markedness in phonology: variation. In Lisa Cheng, ed., The second Glot International state-of-the-article book, 389-429. Berlin: Mouton de Gruyter.

Rosenthal, Franz, J.C. Greenfield, et al., 1986. Aramaic. In Ehsan Yarshater, ed., Encyclopredia Iranica, 250-261. Routledge \& Kegan.

Ross, Malcolm, 1996. Contact-induced change and the comparative method: cases from Papua New Guinea. In Mark Durie, ed., The comparative method reviewed: regularity and irregularity in language change, 180-217. New York: Oxford University Press. 
Ross, Malcolm, 1997. Social networks and kinds of speech-community event. In Roger M. Blench, ed., Archaeology and language, 209-261. London: Routledge.

Ross, Malcolm, 2001. Contact-induced change in Oceanic languages in north-west Melanesia. In R. M. W. Dixon, ed., Areal diffusion and genetic inheritance: problems in comparative linguistics, 134-166. Oxford: Oxford University Press.

Ross, Malcolm, 2003. Diagnosing prehistoric language contact. In Raymond Hickey, ed., Motives for language change, 174-198. Cambridge: Cambridge University Press.

Ross, Malcolm, 2007. Calquing and Metatypy. Journal of Language Contact 1:116-143.

Russell, James, 1997. The Formation of the Armenian Nation. In Richard G. Hovannisian, ed., The Armenian People from Ancient to Modern Times, vol. 1: The Dynastic Periods, from Antiquity to the Fourteenth Century, 19-36. New York: St Martin's Press.

Rutherford, W.E., 1982. Markedness in second language acquisition. Language Learning 32(1): 85-108.

Schmitt, Rüdiger, 1983. Iranisches Lehngut im Armenischen. Revue des Études Arméniennes 17: 73-112.

Schmitt, Rüdiger, 1989. Altpersisch. In Rüdiger Schmitt, ed., Compendium Linguarum Iranicarum, 56-85. Wiesbaden: Dr. Ludwig Reichert.

Schmitt, Rüdiger, 1991. The Bisitun Inscription of Darius the Great. Old Persian Text. London: Published on behalf of Corpus Inscriptionum Iranicarum by the School of Oriental and African Studies.

Schmitt, Rüdiger, 2008. Old Persian. In Roger D. Woodard, ed., The Ancient Languages of Asia and the Americas, 76-100. Cambridge: Cambridge University Press.

Schröder, Peter, 1984. Wortstellung in der deutschen Standardsprache. Versuch einer empirischen Analyse zu topologischen Aspekten von Texten gesprochener Sprache. $\mathrm{PhD}$ thesis, Albert-Ludwigs-Universität zu Freiburg i. Br.

Seifart, Frank, 2015. Does Structural-Typological Similarity Affect Borrowability? A Quantitative Study on Affix Borrowing. Language Dynamics and Change 5: 92-113.

Silva-Corvalán, Carmen, 2008. The Limits of Convergence in Language Contact. Journal of Language Contact 2: 213-224.

Silverstein, Michael, 1974. Dialectal developments in Chinookan tense-aspect systems: an areal-historical analysis. International Journal of American Linguistics 40(4): $45^{-99}$.

Silverstein, Michael, 1977. Person, Number, Gender in Chinook: Syntactic rule and morphological analogy. In K. Whistler, ed., Proceedings of the Third Annual Meeting of the Berkeley Linguistics Society, 143-156. Berkeley: Berkeley Linguistics Society.

Skjærvø, Prods Oktor, 1983. Case in inscriptional Middle Persian, inscriptional Parthian and the Pahlavi Psalter. Studia Iranica 12(1): 69-94, 151-181.

Skjærvø, Prods Oktor, 2009. Old Iranian. In Gernot Windfuhr, ed., The Iranian Languages, 43-195. London: Routledge. 
Stempel, Reinhard, 1983. Die infiniten Verbalformen des Armenischen. Frankfurt a.M./ Bern/New York: Peter Lang.

Strazny, Philipp, ed., 2013. Encyclopedia of Linguistics. Abindgdon: Routledge.

Sundermann, Werner, ed., 1981. Mitteliranische manichäische Texte kirchengeschichtlichen Inhalts. Berlin: Akademie-Verlag.

Swadesh, Morris, 1971. The Origin and Diversification of Language. Chicago: Aldine.

Thomason, Sarah Grey, 1997. Mednyj Aleut. In Sarah Grey Thomason, ed., Contact languages: a wider perspective, 449-468. Amsterdam/Philadelphia:John Benjamins.

Thomason, Sarah Grey, 2000. Contact languages: An introduction. Washington, D.C.: Georgetown University Press.

Thomason, Sarah Grey, 2001. Language Contact: An Introduction. Washington, D.C.: Georgetown University Press.

Thomason, Sarah Grey, 2003. Contact as a Source of Language Change. In Brian D. Joseph, ed., Handbook of Historical Linguistics, 687-712. Malden, MA: Blackwell.

Thomason, Sarah Grey, 2008. Social and Linguistic Factors as Predictors of ContactInduced Change. Journal of Language Contact: $42-56$.

Thomason, Sarah Grey and Terrence Kaufman, 1988. Language Contact, Creolization, and Genetic Linguistics. Berkeley/Los Angeles/Oxford: University of California Press.

Thomson, Robert W., ed., 1980. Patmut' 'iwn Hayots ${ }^{\prime}=$ History of the Armenians. Delmar, NY: Caravan Books.

Thomson, Robert W., ed., 1993. The history of Vardan and the Armenian war. Delmar, NY: Caravan Books.

Tomlin, Russell S., 1986. Basic Word Order: Functional Principles. London: Croom Helm. Toumanoff, Cyril, 1963. Studies in Christian Caucasian History. Georgetown: Georgetown University Press.

Toumanoff, Cyril, 1969. The Third-Century Armenian Arsacids: a Chronological and Genealogical Commentary. Revue des Études Arméniennes 6: 233-281.

Toumanoff, Cyril A Note on the Orontids. Le Museon 72-73: 1-36, 73-106.

Verbeke, Saartje, 2013. Alignment and Ergativity in New Indo-Aryan Languages. Berlin: De Gruyter Mouton.

Vogt, Hans, 1954. Language contacts. Word 10: $365-374$.

Weinreich, Uriel, 1953. Languages in Contact. The Hague: Mouton.

Weiss, Andreas, 1975. Syntax spontaner Gespräche: Einfluss von Situation und Thema auf des Sprachverhalten. Düsseldorf: Pädagogischer Verlag Schwann.

Weitenberg, Johannes J.S., 1986. Infinitive and Participle in Armenian. Annual of Armenian Linguistics 7: 1-26.

Whitehead, J.D., 1978. Some Distinctive Features of the Language of the Arsames Correspondence. Journal of Near Eastern Studies 37: 119-140.

Wurzel, Wolfgang U., 1998. On markedness. Theoretical Linguistics 24(1): 53-71. 